\title{
O Disjuntivismo FenOMÊnico COMO DEFESA DO REALISMO INGÊNUO
}

Phenomenal Disjunctivism as a defense of the Naive Realism

\author{
DANIEL BORGONI \\ Universidade Federal de São Paulo - UNIFESP, BRASIL \\ dborgoni@hotmail.com
}

\begin{abstract}
Phenomenal disjunctivism is put foward in defense of naive realism, the conception of veridical perception according to which physical objects constitute perceptual experience and determine its phenomenal character. However, according to the causal argument we can produce veridical perceptual experiences without physical objects. In defense of naïve realism, phenomenal disjunctivists propose responses to the causal argument mainly based on the characterization of the nature of hallucinatory experience. My aim is to defend that phenomenal disjunctivists do not have succeed in defending naïve realism against the causal argument.
\end{abstract}

Keywords: perceptual experience $\bullet$ veridical perception $\bullet$ hallucination $\bullet$ disjunctivism • phenomenal character

\section{Introdução}

O principal motivo que torna a percepção sensível um fenômeno extraordinário se deve ao fato de ela nos informar sobre eventos e objetos cotidianos, tais como mesas, maçãs, livros e árvores, retratando-os conscientemente para nós. ${ }^{1}$ Por ser uma experiência consciente, a percepção sensível comum envolve uma fenomenologia, ou caráter fenomênico, que é como os aspectos qualitativos experienciados, tais como as cores, aparecem à consciência da pessoa. Ao ver um tomate maduro, a cor vermelha aparece à pessoa sob uma perspectiva subjetiva. Posto de outra maneira, na experiência visual de um tomate maduro, o estado mental perceptivo tem um caráter qualitativo que aparece de certo modo à consciência. Desse modo, o caráter fenomênico diz respeito à natureza das próprias experiências perceptivas.

A experiência perceptiva verídica ${ }^{2}$ parece nos colocar em contato direto com objetos independentes da mente, isto é, parece inexistir alguma entidade mediando o contato perceptivo entre a pessoa e os objetos. Além de entrarem na cadeia causal perceptiva, objetos físicos também parecem contribuir para a estrutura metafísica da percepção, ou seja, para a constituição fundamental das experiências perceptivas. 
Considerando que a pessoa que percebe veridicamente tem contato direto com objetos físicos e que estes objetos contribuem para a constituição experiencial, objetos físicos e suas propriedades são necessários para a ocorrência dos estados mentais perceptivos verídicos. O caráter fenomênico da percepção verídica, portanto, pode ser realizado somente na presença do objeto físico. Atualmente, essa concepção da percepção e da natureza da experiência perceptiva é denominada "visão relacional", ${ }^{3}$ "relacionalismo" ou "realismo ingênuo".

Se objetos físicos são fundamentais para a natureza da percepção verídica, o estado mental perceptivo tem de ser diferente do estado mental alucinatório. Contudo, alucinações introspectivamente indiscrimináveis de percepções verídicas, isto é, alucinações nas quais a pessoa não consegue saber por meio da reflexão sobre sua experiência que está alucinando, ameaçam o realismo ingênuo.

Segundo o argumento da alucinação, percepções verídicas e alucinações indiscrimináveis compartilham o mesmo estado mental. Dado a indiscriminabilidade introspectiva alucinatória, e considerando que toda percepção verídica pode ter como contrapartida uma alucinação indiscriminável, existiria um máximo fator comum que caracterizaria ambas essas experiências como experiências da mesma natureza. Assim, o argumento da alucinação infere a indiscriminabilidade ontológica entre estados mentais da indiscriminabilidade introspectiva alucinatória. Ora, se quem alucina está no mesmo estado mental de quem vê um objeto físico, o realismo ingênuo não se sustenta.

Contra a tese do máximo fator comum e, portanto, contra o argumento da alucinação, filósofos e filósofas têm adotado algum tipo de teoria disjuntivista. De forma geral, o disjuntivismo é a teoria segundo a qual percepções e alucinações são tipos de experiências radicalmente diferentes por não compartilharem o mesmo estado mental.

Embora a encontremos de modo embrionário em Austin (1962), a teoria disjuntivista foi inicialmente explicitada por Hinton (1967). Embora diversas variantes do disjuntivismo tenham sido desenvolvidas, conforme os problemas filosóficos que estavam sendo tratados, podemos dividi-lo em epistêmico e metafísico. O disjuntivismo epistêmico trata de questões relacionadas ao conhecimento, como o problema do mundo exterior. $\mathrm{O}$ estado mental alucinatório seria diferente do estado mental perceptivo, pois a garantia epistêmica que uma pessoa tem quando alucina seria mais fraca do que a evidência que uma pessoa tem nos casos verídicos. Já o disjuntivismo metafísico trata da constituição das experiências perceptivas e defende que o estado mental alucinatório difere do estado mental perceptivo porque tem constituintes diferentes.

Os disjuntivistas afirmam que o máximo fator comum entre percepções verídicas e alucinações está alicerçado numa inferência que é por vezes tomada como evidente. ${ }^{4}$ Porém, ao analisarmos a percepção visual de uma pessoa que vê $X$, o que estaríamos 
autorizados a afirmar é: ou a pessoa viu de fato $X$, e teve uma percepção verídica, ou pareceu-lhe ver $X$, e teve uma alucinação. Não se segue necessariamente de uma alucinação indiscriminável de uma percepção que ambas experiências tenham alguma propriedade em comum que as caracterize como experiências da mesma natureza.

Como o realismo ingênuo é uma concepção sobre a estrutura metafísica perceptiva, sua defesa frente ao argumento da alucinação é feita pelo disjuntivismo fenomênico, um tipo de disjuntivismo metafísico cuja tese central é a de que percepções verídicas e alucinações não compartilham o mesmo caráter fenomênico, ainda que uma alucinação indiscriminável pareça ter a fenomenologia de uma percepção verídica.

Michael Martin (2009[2004], 2006) e William Fish (2008, 2009), os principais representantes do disjuntivismo fenomênico, exploram o seguinte raciocínio: dado que a inferência entre a indiscriminabilidade introspectiva e a indiscriminanilidade fenomênica não está dada, não se segue que alucinações indiscrimináveis compartilham o caráter fenomênico que faria das percepções verídicas experiências sui generis. Embora admitam alucinações indiscrimináveis de percepções sob uma perspectiva de primeira pessoa, ${ }^{5}$ os disjuntivistas fenomênicos negam que a indiscriminabilidade fenomênica decorra da indiscriminabilidade introspectiva alucinatória. A indiscriminabilidade alucinatória proviria da incapacidade introspectiva de a pessoa discriminar sua alucinação de uma percepção verídica. Ou seja, além de levar a pessoa à falsa crença de que está percebendo objetos externos, uma alucinação leva quem alucina a atribuir, erroneamente, fenomenologia perceptiva à alucinação. Portanto, para os disjuntivistas fenomênicos, ${ }^{6}$ a introspecção não é um sentido interno por meio do qual a pessoa observa os próprios estados mentais, capacitando-a a conhecer as propriedades da sua experiência ou reconhecer sua ausência.

Entretanto, a tese do máximo fator comum fenomênico pode ser defendida por meio de um argumento mais poderoso: o argumento causal da alucinação. Para entendermos como o argumento causal desafia a tese na qual objetos independentes da mente têm um papel constitutivo nas experiências perceptivas verídicas, precisamos saber quais são os compromissos teóricos aos quais o realista ingênuo adere. Isso será o tema da seção 2, dedicada ao escrutínio do realismo ingênuo. Na seção 3 , esmiuçaremos o argumento causal. Veremos que os disjuntivistas fenomênicos adotam uma resposta comum contra o argumento causal, mas que essa resposta gera indeterminação fenomênica na percepção verídica. Em defesa do realismo ingênuo, Martin (2009[2004], 2006) e Fish (2008, 2009) propõem variantes do disjuntivismo fenomênico, respectivamente expostos e analisados nas seções 4 e 5 . Ao longo dessas seções, analisarei os argumentos a favor e contra tais disjuntivismos fenomênicos, concluindo que nenhum deles consegue defender o realismo ingênuo contra o argumento causal. 


\section{A natureza da percepção verídica}

Embora discordem sobre a natureza das alucinações e sobre o que faz com que sejam introspectivamente indiscrimináveis de percepções, Martin (2009[2004], 2006) e Fish $(2008,2009)$ concordam que a natureza das percepções verídicas é adequadamente capturada pelo realismo ingênuo.

... algumas experiências sensoriais são relações com objetos independentes da mente. Isto quer dizer que, tomando as experiências como episódios e eventos, o realista ingênuo supõe que alguns episódios têm como constituintes objetos independentes da mente (Martin 2006, p.354).

Assim, a percepção verídica tem um caráter relacional no qual a experiência é uma mera relação entre particulares e suas propriedades e uma pessoa, ou seja, nada mais caracterizaria a experiência perceptiva verídica além desse caráter relacional. Não existiriam conteúdos representacionais etc. caracterizando a estrutura metafísica perceptiva, por exemplo. Objetos físicos seriam algo mais do que o elo causal inicial da cadeia perceptiva, ou, nas palavras de Hellie, "o objeto [físico] é um participante do fato psicológico, antes que externo a ele" $(2009$, p.6). Se objetos físicos e suas propriedades contribuem constitutivamente para a experiência, a determinação do caráter fenomênico depende da relação perceptiva entre a pessoa e o objeto no mundo. Nesse sentido:

...nós deveríamos entender a afirmação do realista ingênuo de que objetos externos e suas propriedades circunscrevem os contornos da experiência consciente da pessoa: eles circunscrevem os contornos da experiência consciente da pessoa por, de fato, serem os contornos da experiência consciente da pessoa (Fish 2009, p.6).

Ao conceber o realismo ingênuo em termos fenomênicos, o disjuntivista se compromete com as teses metafísicas nas quais a percepção dos objetos no mundo é direta e objetos externos e suas propriedades são o que determina a fenomenologia perceptiva verídica. Se não existe mediação entre quem percebe e se a percepção é uma mera relação entre particulares e uma pessoa, a experiência é suficiente para o contato perceptivo. A suficiência da experiência em colocar a pessoa em contato com o objeto significa que a experiência não é entendida como um elemento independente da estrutura perceptiva, tal como os conjuntivistas afirmam. ${ }^{7}$ Desse modo, experiências perceptivas não têm qualquer papel explicativo autônomo em relação às suas naturezas, pois a concepção da experiência depende da concepção que se tem da percepção.

Para Martin (2009[2004], 2006) e Fish $(2008,2009)$, entender a percepção verídica como uma mera relação entre particulares e pessoas implica dizer que a relação 
perceptiva é cognitivamente primitiva. A percepção verídica seria uma relação de $a c$ quaintance entre objetos públicos e quem os percebe, onde acquaintance é o contato perceptivo direto no qual: i) a pessoa encontra-se numa relação mental com os objetos no mundo que é irredutível, ou seja, não pode ser decomposta ou reduzida a itens mais elementares; e ii) existe um tipo de acesso epistêmico especial aos objetos, dado pelo modo como os objetos e suas propriedades se apresentam perceptivamente à consciência. ${ }^{8}$

Então, o disjuntivista se contrapõe à identificação do evento mental que ocorre na percepção verídica com eventos físicos cerebrais e nega a tese da sobreveniência do mental em relação ao físico. ${ }^{9}$ Quando se defende o fisicalismo de identidade, experiências perceptivas são eventos ou estados mentais que ocorrem no final da cadeia causal perceptiva, pois existiria uma relação de identidade entre estado mental perceptivo e estado cerebral correlato. Essa identificação não pode ser admitida pelo disjuntivista, pois reduziria a experiência ao que ocorre no cérebro.

O disjuntivismo é incompatível com a tese da sobreveniência. ${ }^{10}$ Considerando a sobreveniência do mental em relação ao cerebral, as propriedades de baixo nível são os estados ou processos cerebrais, e o que compõem o estado mental perceptivo são as propriedades de alto nível. Estados mentais perceptivos não seriam redutíveis a estados cerebrais, mas seriam dependentes e determinados por estados cerebrais, violando a tese realista ingênua de que objetos físicos são necessários para a determinação e constituição da experiência perceptiva verídica.

\section{3. $\mathrm{O}$ argumento causal}

O realismo ingênuo parece conflitar com considerações causais segundo as quais poderíamos obter a experiência ocorrente na percepção verídica na ausência do objeto físico ao estimularmos algum elo da cadeia causal perceptiva do mesmo modo que esse elo seria estimulado numa percepção verídica.

De modo simplificado, mas suficiente para nosso objetivo, podemos descrever a cadeia causal perceptiva do seguinte modo. A luz refletida no objeto físico (elo causal distal) atinge a retina estimulando os nervos ópticos que se ligam com o núcleo geniculado lateral do tálamo que, por sua vez, se conectam com o córtex visual primário, que, então, envia informações relativas à visão parcialmente processadas para diversas regiões do córtex associadas à visão. Existiria, então, um estado cerebral suficiente para determinar a experiência visual da pessoa.

Desse modo, atuando-se em algum elo da cadeia causal perceptiva visual, do mesmo modo que esse elo seria estimulado na percepção verídica, garantiríamos que os estágios posteriores da cadeia causal àquele estágio que foi estimulado artificialmente seriam os mesmos. Teríamos, então, uma alucinação causada pelos estados do 
cérebro que causam a correspondente percepção verídica. Considerando que produziríamos artificialmente uma alucinação introspectivamente indiscriminável de uma percepção, e que os estados neurais são os mesmos em ambas as experiências, podese inferir que a experiência alucinatória é a mesma experiência que a pessoa tem ao ver um objeto físico. Em outras palavras, poderíamos criar uma alucinação com a fenomenologia da percepção verídica, estimulando diretamente o córtex visual tal como o córtex visual é estimulado na percepção verídica, pois em ambos os casos teríamos o mesmo estado cerebral. Dado que uma alucinação não necessita do objeto no mundo para ocorrer, e se uma alucinação é o mesmo tipo de experiência que uma percepção, não precisamos do objeto físico para a ocorrência da experiência perceptiva verídica. Isso implica que objetos físicos não são necessários para a constituição da experiência perceptiva verídica, colocando em xeque o realismo ingênuo.

Vemos, então, que o princípio da mesma causa, mesmo efeito está implícito no argumento causal. Ou seja, como alucinações e percepções podem ter as mesmas causas, isto é, os elos proximais da cadeia perceptiva de ambas experiências podem ser os mesmos, as experiências teriam a mesma natureza, uma vez que as mesmas causas devem produzir os mesmos efeitos. Em outras palavras, o mesmo estado cerebral garantiria a identidade experiencial e, assim, a identidade fenomênica entre uma percepção verídica e uma alucinação indiscriminável. Se o que conta para a determinação fenomênica é o que ocorre somente no final da cadeia causal perceptiva, é falso que objetos físicos são necessários na determinação fenomênica da percepção verídica.

Em defesa do realismo ingênuo, talvez se possa pensar que poderíamos alegar que experimentalmente não conseguimos ainda replicar uma alucinação causalmente condizente, isto é, alucinações introspectivamente indiscrimináveis produzidas através das mesmas condições causais proximais de uma percepção verídica. Contudo, a meu ver, essa não seria uma resposta adequada contra o argumento causal, por dois motivos: 1) não elimina a possibilidade das alucinações indiscrimináveis. Um dia, talvez, consigamos replicar em laboratório precisamente as condições neurais ocorrentes na percepção visual na ausência do objeto físico e; 2) Segundo Ffytche (2013, p.54), evidências empíricas obtidas pelo escaneamento do cérebro de uma pessoa alucinando mostram atividade na área de especialização do seu córtex visual similar àquela quando a pessoa percebe veridicamente. Por exemplo, quando a pessoa alucina um rosto, a área do córtex visual especializada no reconhecimento de rostos está ativa.

Os disjuntivistas, porém, oferecem outra resposta contra o argumento causal. Embora aceitem a possibilidade de produzirmos alucinações causalmente condizentes, argumentam que condições não causais interferem na natureza da experiência ocorrente na percepção verídica. Isso implica se posicionar contra o princípio da mesma causa, mesmo efeito. A experiência perceptiva não ocorreria somente no final da 
cadeia causal perceptiva, pois objetos físicos seriam as condições não causais que constituem a experiência perceptiva e determinam seu caráter fenomênico. Como não está circunscrita ao final da cadeia causal, a experiência não pode ser idêntica a um evento cerebral.

Então, embora endosse o princípio da mesma causa, mesmo efeito quando aplicado às conexões que relacionam leis físicas e objetos públicos, o disjuntivista nega que este princípio se aplique às conexões causais de natureza psicofísica de modo irrestrito. Não se trata de negar que nossas experiências façam parte da ordem causal natural (e por isso sujeitas a causas naturais), mas de negar a suficiência dos processos cerebrais para a realização da fenomenologia perceptiva verídica.

Assim, o disjuntivista admite um princípio da mesma causa, mesmo efeito restrito: para que um evento mental 1 seja do mesmo tipo que um evento mental 2, além das condições causais proximais que geram o evento 1 terem de ser as mesmas condições causais proximais que geram o evento 2 , o evento 1 e o evento 2 não podem diferir nas condições não causais necessárias para a ocorrência do evento mental 2.

Mediante o princípio causal restrito, uma alucinação causalmente condizente não pode ser o mesmo evento mental que ocorre na percepção verídica. Ainda que ambos os eventos possam compartilhar condições causais proximais, tais como estados neurais, a alucinação difere da percepção por não ter a condição não causal necessária que determina a percepção verídica: o objeto físico. Assim, por não ter a condição não causal necessária determinante do caráter fenomênico verídico, o estado mental alucinatório é diferente do estado mental perceptivo, salvaguardando o realismo ingênuo.

Entretanto, se, de um lado, a adesão ao princípio causal restrito permite ao disjuntivista contornar o argumento causal, por outro, gera o problema da redundância explicativa: objetos físicos seriam redundantes na determinação fenomênica da percepção verídica. Vejamos como esse problema surge.

Dado o princípio causal restrito, uma alucinação não tem a condição não causal necessária para a ocorrência do estado mental perceptivo, pois o objeto físico está ausente. Inversamente, não existem condições não causais necessárias para uma alucinação ocorrer que estejam ausentes na percepção. Se alucinações e percepções podem ter as mesmas condições causais proximais e se não existem condições não causais necessárias para uma alucinação e ausentes numa percepção, "qualquer que seja o tipo mais específico de evento que ocorre quando temos uma alucinação causalmente condizente, o mesmo tipo de evento ocorre quando temos uma percepção verídica" (Martin 2006, p.369).

Desse modo, o disjuntivista pode aceitar que uma alucinação compartilhe seu caráter fenomênico com a percepção correspondente, sem ter de aceitar que o estado mental perceptivo verídico tenha seu caráter fenomênico compartilhado com a respectiva alucinação, pois falta às experiências alucinatórias a condição não causal 
necessária para a determinação da fenomenologia perceptiva verídica. O disjuntivista, assim, pode recorrer à fenomenologia que uma alucinação teria em comum com uma percepção verídica para explicar a indiscriminabilidade alucinatória, sem ter, por isso, de endossar que o caráter fenomênico perceptivo verídico seja realizado na alucinação.

Contudo, se quiser defender o realismo ingênuo, o disjuntivista não pode se basear somente na resposta contra o argumento causal que se baseia no princípio causal restrito, pois colocaria o disjuntivismo fenomênico numa posição instável em relação à determinação fenomênica da percepção verídica. Essa instabilidade é capturada pelo problema da redundância explicativa:

Se existe um tipo comum entre percepções verídicas e alucinações causalmente condizentes, o que mostra que o que é relevante para as explicações que queremos oferecer é sempre um tipo de evento peculiar às percepções verídicas antes que o que é comum às percepções verídicas e alucinações causalmente condizentes? (Martin 2006, p.369).

Se aquilo que determina o caráter fenomênico alucinatório está presente na percepção correspondente, cabe ao disjuntivista mostrar que a condição relevante para uma experiência ser uma percepção verídica não separe as propriedades peculiares que $o$ realista ingênuo supõe existirem na percepção verídica do papel explicativo que essas propriedades teriam para a natureza da experiência perceptiva verídica. Em outras palavras, é preciso garantir que o caráter fenomênico compartilhado entre alucinações e percepções não entre em competição explicativa com o que o realista ingênuo supõe que uma percepção verídica tem de único, o caráter fenomênico realista ingênuo.

O problema da redundância explicativa pode, ainda, ser posto em outros termos. Caso tenhamos a fenomenologia alucinatória determinando a experiência perceptiva verídica, não temos a necessidade de postular um caráter fenomênico realista ingênuo. Isso faria com que o que se supõe que uma percepção verídica tem de único objetos físicos - se torne redundante para a explicação da fenomenologia perceptiva verídica.

A resposta ao problema da redundância explicativa e, consequentemente ao argumento causal, passa pela caracterização da natureza alucinatória, e é essa caracterização o que, principalmente, diferenciará o disjuntivismo fenomênico de Martin (2009[2004], 2006) do disjuntivismo fenomênico de Fish $(2008,2009)$.

\section{O disjuntivismo negativo}

Em resposta ao problema da redundância explicativa, Martin propõe o critério epistêmico negativo: 
Para certas experiências visuais de uma cerca branca, a saber, alucinações causalmente condizentes, não existe nada mais para o caráter fenomênico de tais experiências que ser indiscriminável das percepções verídicas correspondentes de uma cerca branca. (Martin 2006, p.369).

Ou seja, tudo o que podemos afirmar sobre a natureza mental de uma alucinação indiscriminável é que ela é indiscriminável de uma percepção, pois a fenomenologia alucinatória seria caracterizada somente por essa indiscriminabilidade. Uma alucinação não teria características ou propriedades adicionais à propriedade de ser indiscriminável de uma percepção verídica, ou propriedade da indiscriminabilidade. Assim, uma alucinação compartilha com uma percepção somente o fato de ser indiscriminável e o caráter fenomênico alucinatório é determinado pela propriedade da indiscriminabilidade.

Desse modo, a fenomenologia alucinatória é explicada somente pela satisfação da condição epistemológica de que a alucinação é indiscriminável da percepção correspondente, reduzindo a natureza da experiência alucinatória à propriedade da indiscriminabilidade. Nas alucinações não existiriam "objetos da consciência”, expressão que utilizarei para me referir a ideia de "constituintes mentais", sem especificar sua ontologia. Uma alucinação não tem constituinte mental, pois é caracterizada somente em termos epistemológicos.

Por ser um critério epistêmico que determina a natureza alucinatória e por que a pessoa que alucina não pode saber por introspecção que a fenomenologia alucinatória não é a fenomenologia perceptiva verídica, o disjuntivismo de Martin (2009[2004], 2006) é um disjuntivismo negativo.

Considerando que a propriedade da indiscriminabilidade determina a fenomenologia alucinatória e uma alucinação compartilha a propriedade da indiscriminabilidade com a correspondente percepção, não existe mais a possibilidade de o caráter fenomênico alucinatório especificar o evento mental que os realistas ingênuos atribuem somente às percepções verídicas, uma vez que nada mais existe para a natureza mental alucinatória do que a propriedade da indiscriminabilidade.

Martin (2009 [2004], 2006), então, evita o problema da redundância explicativa ao eliminar a possibilidade de objetos dependentes da mente determinarem a fenomenologia alucinatória, pois não existe mais a competição entre objetos dependentes da mente e objetos físicos na determinação fenomênica da percepção verídica. Ou seja, não existe a possibilidade de o caráter fenomênico perceptivo ser explicado por objetos dependentes da mente. Embora exista uma fenomenologia compartilhada entre alucinações e percepções — a fenomenologia alucinatória — não existe o problema da separação das propriedades fenomênicas ingênuas do seu papel na determinação da natureza da experiência perceptiva verídica.

O disjuntivismo negativo endossa o princípio fenomênico somente para as percepções verídicas. ${ }^{11}$ Se uma pessoa vê um tomate maduro, então existe um tomate 
do qual a pessoa está consciente que tem a qualidade de ser vermelho. Já na alucinação indiscriminável de um tomate maduro, o consequente do princípio fenomênico "se ...então" não é admitido pelo disjuntivista, pois não existiria nada do qual a pessoa está consciente que possui a qualidade de ser vermelho que o tomate alucinado parece possuir. A perspectiva de primeira pessoa não garante a quem alucina a aquisição do conhecimento que mostraria que a fenomenologia alucinatória não é a fenomenologia perceptiva.

A indiscriminabilidade introspectiva não implica que o que aparece à consciência da pessoa, isto é, o que a perspectiva de primeira pessoa possa lhe informar, envolva sempre um objeto da consciência. Embora a indiscriminabilidade alucinatória se refira a um ponto de vista da pessoa sobre o mundo, ou perspectiva em primeira pessoa de quem alucina, ela não se refere à existência de algo no nível mental.

Considerando que uma alucinação é uma experiência sensorial, ${ }^{12}$ seu caráter sensorial é explicado pela propriedade da indiscriminabilidade, uma vez que a "indiscriminabilidade fornece condições suficientes para um evento [uma alucinação] ser uma experiência sensorial" (Martin 2009[2004], p.303). Se a fenomenologia alucinatória pode ser tipificada somente por uma condição epistemológica, não se exige nada mais para a natureza de uma experiência sensorial do que a propriedade de ser indiscriminável de uma percepção verídica. E como experiências sensoriais envolvem estados mentais sensoriais, podem "existir estados sensoriais cuja natureza mental seja caracterizável por nada além de termos epistemológicos" (Martin 2009[2004], p.272).

Em suma, embora a percepção verídica porte a propriedade da indiscriminabilidade, a caracterização da natureza alucinatória pelo critério epistêmico negativo garante que objetos físicos determinem a fenomenologia perceptiva verídica, salvaguardando o realismo ingênuo.

\subsection{A não suficiência do critério epistêmico negativo}

Segundo a objeção de Smith (2002), o critério epistêmico negativo é insuficiente para explicar as experiências alucinatórias:

... dizer que o sujeito não está consciente de nada [na alucinação] é certamente sub-descrever a situação dramaticamente. Talvez isso faça algum sentido para "pensamentos simulados", mas pode realmente existir algo como uma consciência sensorial simulada? Talvez possa existir "uma ilusão do entendimento", mas pode existir uma ilusão da consciência? ... as características sensoriais da situação precisam ser explicadas. Como fazer isso se é negado que o sujeito está diante de um objeto da consciência? (Smith 2002, pp.224-5).

Talvez se possa falar em ilusão da consciência sensorial quando consideramos os 
sonhos, mas essas experiências não são sensoriais. Dizer que a pessoa que alucina não está consciente de nada seria admitir uma ilusão da consciência nas alucinações, porém, alucinações "envolvem um estado [mental] consciente que é sensorial em caráter" (Smith 2002, p.225). Para explicar para o que a atenção da pessoa se dirige numa alucinação "não é suficiente afirmar que a pessoa está utilizando conceitos, tendo uma visualização, e engajado em descrever pensamentos" (Smith 2002, pp.224-5). Assim:

A menos que algo mais seja dito, nós somos deixados sem quaisquer meios de distinguir os casos alucinatórios que nos interessam de estados totalmente diferentes, como as sugestões pós-hipnóticas, as confusões mentais, a desatenção, jumping the gun ${ }^{13}$ e assim por diante (Smith 2002, p.225).

Se caracterizarmos epistemicamente a natureza alucinatória pela propriedade da indiscriminabilidade, não teremos recursos para selecionar experiências sensoriais entre experiências em geral, pois o caráter sensorial alucinatório seria negligenciado. Alucinações seriam alocadas no grupo das experiências não sensoriais, pois o disjuntivismo negativo não teria um marco de diferenciação entre experiências sensoriais e experiências não sensoriais. Posto em outros termos, circunscrever a fenomenologia alucinatória pela propriedade da indiscriminabilidade negligencia o caráter sensorial alucinatório, uma vez que o critério epistêmico negativo agrupa sonhos e alucinações no mesmo grupo de experiências. Ao não explicar o que aparece no cenário que se apresenta à consciência da pessoa que alucina, o critério epistêmico negativo é insuficiente para uma experiência ser sensorial e, assim, insuficiente para explicar a natureza alucinatória.

Martin (2006, p.374) concorda que alucinações são experiências sensoriais e sugestões pós-hipnóticas e sonhos são experiências não sensoriais, porém, discorda da insuficiência de o critério epistêmico negativo discriminar alucinações de experiências não sensoriais.

Em réplica a Smith (2002), Martin (2006, p.381) propõe um marco demarcatório entre experiências sensoriais e experiências não sensoriais, associando a noção de impessoalidade à indiscriminabilidade introspectiva. Teríamos a indiscriminabilidade introspectiva pessoal e a indiscriminabilidade introspectiva impessoal. A indiscriminabilidade pessoal envolve experiências que parecem indiscrimináveis introspectivamente por existir algum impedimento de ordem pessoal afetando o julgamento da pessoa sobre sua experiência. A experiência visual que Débora julgou indiscriminável de uma percepção verídica se revelaria impessoalmente discriminável de uma percepção genuína se o julgamento fosse feito por Cristina, pois Cristina não é afetada pelo impedimento que afetou o julgamento de Débora. Existe uma situação ótima, ou situação possível que mostraria que a indiscriminabilidade envolvida na incapacidade discriminatória é de ordem pessoal. Consequentemente, não se segue 
das experiências pessoalmente indiscrimináveis que sejam indiscrimináveis no nível impessoal.

Já a indiscriminabilidade impessoal é a que o disjuntivismo negativo utiliza. Segundo Martin (2009 [2004], p.304), uma experiência é indiscriminável de uma percepção verídica por meio da reflexão introspectiva quando a indiscriminabilidade envolver uma forma impessoal de incapacidade discriminatória. Uma experiência será impessoalmente indiscriminável de uma percepção quando "não for possível saber por meio da introspecção sozinha que essa não é uma situação perceptiva verídica" (Martin 2009[2004], p.304). A experiência indiscriminável impessoalmente "requer uma impossibilidade epistêmica impessoal de algum tipo" (Sturgeon 2008, p.127). Então, a incapacidade discriminatória será impessoal quando não existir uma situação possível na qual possa haver discriminação. Passarão pelo critério da impessoalidade as experiências cujos juízos sobre sua indiscriminabilidade forem baseados somente na reflexão introspectiva, de modo que somente experiências sensoriais atendem a esse critério.

Desse modo, Smith (2002) se equivocaria ao afirmar que a adoção do critério epistêmico negativo impede que o disjuntivismo negativo consiga discriminar alucinações de experiências não sensoriais, tendo em vista que ambas as situações envolvem noções de indiscriminabilidade distintas. Alucinações são indiscrimináveis impessoalmente, porém, sugestões pós-hipnóticas e sonhos são indiscrimináveis pessoalmente, pois nesses casos algum impedimento pessoal interfere no julgamento da pessoa, impedindo-a de saber que não está tendo uma percepção verídica. Assim, por utilizar outro sentido de indiscriminabilidade, a objeção de Smith (2002) não atingiria o disjuntivismo negativo. Se a indiscriminabilidade impessoal é o marco demarcatório entre experiências sensoriais e experiências não sensoriais, o disjuntivismo negativo fornece as condições suficientes para que uma alucinação seja uma experiência sensorial.

Em tréplica, Smith (2008) contesta Martin (2006):

... essa distinção entre duas noções de indiscriminabilidade não ajudarão frente às minhas experiências não sensoriais [o sonho, a hipnose e o falso positivo], uma vez que essas são absoluta e impessoalmente indiscrimináveis de percepções. Não existe situação possível na qual elas poderiam ser discriminadas: nenhuma situação "ótima", como podemos colocar (Smith 2008, p.187).

Smith (2008) explora o seguinte raciocínio: se sonhos, sugestões pós-hipnóticas e falsos positivos são indiscrimináveis pessoalmente de percepções verídicas, deve existir uma situação ótima na qual a pessoa nessas experiências não sensoriais discrimine sua experiência de uma percepção verídica. Comecemos pelos sonhos.

Efetivamente, existe uma limitação na capacidade reflexiva da pessoa que sonha que a impede de saber que está sonhando, denominada single-mindedness. Esse seria 
o impedimento que mostraria que os sonhos são indiscrimináveis pessoalmente de percepções. Nesse caso, estar dormindo é o fato que impede a pessoa de discriminar seu sonho de uma percepção, porém, dizer que essa incapacidade discriminatória se deve ao fato de a pessoa estar dormindo é o mesmo que declarar que "pessoas que estão dormindo poderiam informar que elas estavam dormindo se elas estivessem acordadas" (Smith 2008, p.188). Pensar o impedimento pessoal nestes termos é um absurdo, pois parece analítico que se sonha, uma pessoa está dormindo.

Ora, mas se sonhos ordinários não podem ser postos a favor do disjuntivismo negativo, sonhos lúcidos podem, pois é "possível que qualquer sonho poderia ter sido, ou poderia tornar-se, lúcido" (Smith 2008, p.188). Sonhos lúcidos seriam a situação ótima na qual a pessoa discrimina sonhos de percepções. Entretanto, mesmos os sonhos lúcidos não poderiam ser utilizados a favor do disjuntivismo negativo. $\mathrm{O}$ problema residiria no que faz com que o sonho se torne lúcido, tais como conteúdos bizarros ou repetitivos:

...tais modos de determinar se alguém está sonhando não são em absoluto o que os defensores do critério epistêmico negativo querem dizer por discriminar uma experiência de uma percepção verídica "através da reflexão" ou "somente com base na experiência" (Smith 2008, p.189).

De forma mais clara, o disjuntivista negativo não pode recorrer aos sonhos lúcidos porque, ao se basear nas características bizarras ou repetitivas para saber que está sonhando, a pessoa não está baseando seu julgamento na reflexão introspectiva para fazer a discriminação. Lembremos que essa é a exigência básica para que uma pessoa julgue sua experiência indiscriminável. Se depender de características bizarras ou da recorrência onírica para separar sonhos de percepções verídicas, no que tange ao caráter sensorial, o disjuntivismo negativo tem de utilizar estes mesmos indicadores para separar alucinações bizarras de percepções verídicas. Ao utilizarmos conteúdos bizarros para mostrar que os sonhos são indiscrimináveis pessoalmente, temos de aplicar o mesmo critério às alucinações bizarras, pois para o disjuntivismo negativo uma experiência é sensorial desde que o juízo sobre sua indiscriminabilidade seja baseado na reflexão introspectiva. Na alucinação bizarra, a pessoa vem a saber que não está tendo uma percepção verídica por causa do conteúdo bizarro, mas teríamos de admitir que alucinações bizarras não são experiências sensoriais, pois elas seriam apartadas de alucinações indiscrimináveis ordinárias pelo seu conteúdo bizarro. Então, o apelo às características bizarras continuaria colocando alucinações e sonhos no mesmo grupo de experiências, pois os sonhos seriam impessoalmente indiscrimináveis de percepções verídicas. Se os sonhos lúcidos não são a situação ótima que mostra que sonhos são indiscrimináveis pessoalmente de percepções, os sonhos, tal como as alucinações, são indiscrimináveis impessoalmente das percepções verídicas. O critério epistêmico negativo, então, não é suficiente para diferenciar alucinações 
de experiências não sensoriais.

A meu ver, o argumento que Smith (2002) constrói para objetar a suficiência do critério epistêmico negativo para a natureza alucinatória que se baseia nos sonhos não é decisivo contra o disjuntivismo negativo, porém, enfraquece essa teoria. A princípio, parece razoável afirmar que sonhos lúcidos são a situação possível na qual a pessoa discrimina sua experiência de uma percepção verídica. Ora, a pessoa quando se torna lúcida, sabe que está sonhando. É razoável afirmar que, se considerarmos que o caráter fenomênico alucinatório é sua propriedade da indiscriminabilidade, temos de admitir que os sonhos lúcidos são impessoalmente indiscrimináveis de percepções, pois são selecionados pelo critério epistêmico negativo.

Considerando a questão por outro olhar, talvez os sonhos lúcidos não sejam os melhores exemplos de experiências para mostrar a insuficiência do critério epistêmico negativo, uma vez que podemos questionar justamente o caráter não sensorial dos sonhos. Ainda que Martin (2006) e Smith (2008) concordem que sonhos são experiências não sensoriais, se alucinações são consideradas experiências sensoriais em caráter, talvez os sonhos também o sejam. Seriam os sonhos uma espécie de alucinação?

A resposta parece ser negativa se entendermos os sonhos como uma espécie de visualização mental, porém, seria razoável responder positivamente se considerarmos a impressionante clareza visual e nitidez do cenário que se apresenta à pessoa em certas experiências oníricas. Nesse sentido, Cecilia Green (1968, p.70), em sua pesquisa, concluiu que existem sonhos lúcidos que parecem uma reprodução acurada da experiência que temos quando estamos acordados. Relatos de experiências oníricas coletados pela pesquisadora parecem mostrar que em tais experiências a pessoa está como se estivesse "sonhando acordada", pois sabe que está sonhando, mas parece estar percebendo veridicamente. Nas palavras de Green, é comum os sonhos lúcidos terem uma textura perceptiva, pois "nos sonhos lúcidos os relatos da completa clareza visual e completude de cor são comuns" (1968, p.71). Ou seja, tal como alucinações podem parecer tão vívidas quanto percepções verídicas, existiriam sonhos que são tão vívidos quanto percepções verídicas. Desse modo, a vividez onírica deporia a favor da atribuição aos sonhos de um caráter sensorial. Portanto, talvez não tenha sentido diferenciar os sonhos das alucinações no que concerne ao seu caráter sensorial. Por isso, é razoável afirmar que os sonhos não são decisivos contra o disjuntivismo negativo.

E as sugestões pós-hipnóticas, seriam impessoalmente ou pessoalmente indiscrimináveis de percepções? Para Martin (2006), experiências hipnóticas são indiscrimináveis pessoalmente, pois existiria algum impedimento de ordem pessoal que faz com que o hipnotizado não discrimine sua experiência de uma percepção genuína.

Contrariamente, para Smith (2008), a indiscriminabilidade impessoal aplicar-seia tanto à hipnose quanto à alucinação, pois não existiria situação possível na qual 
a pessoa hipnotizada possa estar e concluir, com base na reflexão introspectiva sobre sua experiência, que não está tendo uma percepção verídica. Desse modo, o que a sugestão pós-hipnótica mostra é que, ao considerarmos o critério epistêmico negativo como um fator suficiente para experiências sensoriais, teremos de admitir, erroneamente, que experiências hipnóticas são experiências sensoriais, pois o critério epistêmico negativo também as seleciona. Como não é uma experiência sensorial, a hipnose mostraria que o disjuntivismo negativo não fornece condições suficientes para que uma alucinação seja uma experiência sensorial, uma vez que não diferencia hipnoses de alucinações.

Efetivamente, Smith (2008) trata de modo sucinto a hipnose, dando a entender que o ônus da prova está com Martin (2006), que deve mostrar que o critério epistêmico negativo separa experiências hipnóticas de alucinações. Então, exploremos mais as experiências hipnóticas para avaliarmos a força dos argumentos do objetor.

O que a pesquisa empírica mostra é que parece existir um rebaixamento ou inibição da capacidade cognitiva que a pessoa hipnotizada tem de refletir sobre a sua experiência. ${ }^{14}$ Todavia, não vem ao caso saber se podemos alcançar uma situação possível na qual a pessoa hipnotizada poderia discriminar sua experiência de uma percepção verídica, na medida em que o problema com a resposta de Smith (2008) é considerar a priori que a hipnose é uma experiência não sensorial.

A hipnose é um fenômeno bastante complexo, pois pode envolver crenças falsas, insensibilidade a dor, alterações da autoimagem e, ao que parece, alucinações. Ao tratar a hipnose somente como uma experiência não sensorial, Smith (2008) descarta de antemão a possibilidade de que a experiência hipnótica visual envolva alucinações e é nisso que reside a fraqueza do seu argumento. Vários pesquisadores defendem que a hipnose envolve alucinações. ${ }^{15}$ Isso parece ocorrer quando o hipnotizador induz a pessoa a "ver" algo que não está lá. Assim, não tem sentido utilizar a hipnose para objetar o critério epistêmico negativo, uma vez que a hipnose pode envolver alucinação. Ora, se esse for o caso, é normal que a hipnose atenda ao critério epistêmico negativo, pois envolveria uma experiência sensorial.

Como a questão de saber se a hipnose envolve alucinações ou não é uma questão a ser estabelecida empiricamente e Smith (2008) estabelece de antemão que a hipnose é uma experiência não sensorial, sua crítica ao disjuntivismo negativo perde o ponto.

Por fim, tratemos dos falsos positivos, experiências não sensoriais que ocorrem no experimento do taquitoscópio, um aparelho que projeta imagens numa tela por breves períodos de tempo para testar a percepção visual. Consideremos os seguintes estados psicológicos no experimento: a) uma percepção verídica, pois algo realmente foi projetado na tela; b) uma alucinação, casos nos quais as pessoas estariam erradas ao dizer que algo foi projetado na tela, mas estariam certas em afirmar que tiveram uma experiência sensorial e; c) o falso positivo, caso no qual a pessoa pensa que viu algo, mas erra ao crer que viu algo na tela e erra ao pensar que teve uma experiência 
sensorial.

Smith afirma que "os disjuntivistas que aderem ao critério epistêmico negativo são incapazes de discriminar os últimos dois casos [a alucinação e o falso positivo], uma vez que estes são reflexivamente indiscrimináveis do primeiro, o caso perceptivo" (2008, p.185). Se nos falsos positivos a pessoa não consegue saber se teve uma percepção verídica baseando-se somente na reflexão sobre a sua experiência, como diferenciar alucinações dos falsos positivos com base na indiscriminabilidade impessoal?

O disjuntivista poderia dizer que a brevidade das projeções impede a pessoa de discriminar o falso positivo de uma experiência sensorial. Existiria, então, uma situação possível na qual a pessoa poderia realizar tal discriminação. Se a restrição temporal inerente ao experimento do taquitoscópio é o impedimento que incapacita a pessoa de estar na situação ótima para fazer a discriminação, como contornar essa limitação e mostrar que a indiscriminabilidade envolvida nos falsos positivos é de ordem pessoal?

Segundo Smith (2008), o disjuntivista pode recorrer a duas situações possíveis para contornar a limitação temporal do experimento do taquitoscópio: ou considerar uma situação na qual a restrição temporal do experimento originário é suspensa ou considerar a situação hipotética da existência de um ser para quem essa brevidade não seria um problema. Tratemos de ambas as situações.

Consideremos a situação cotidiana na qual João não foi capaz de discriminar o remendo, feito por um costureiro em sua roupa, do tecido da roupa porque não teve tempo suficiente para isso. Analogamente, podemos supor que estender o tempo de projeção das imagens na tela permitiria à pessoa atribuir aos falsos positivos uma natureza não sensorial, pois viria a saber que apenas pensou ter visto algo. No entanto, Smith (2008, p.194) observa, quando se aumenta o tempo para João discriminar o remendo do tecido da roupa, o objeto da discriminação continua o mesmo, porém, quando se aumenta o tempo de projeção das imagens do taquitoscópio, modificase o objeto de estudo desse experimento. A experiência estendida pode contornar o problema da brevidade, mas ela não seria a mesma experiência momentânea do taquitoscópio.

Ora, mas o disjuntivista poderia alegar que "uma extensão deveria envolver mais do mesmo, não uma continuação para uma experiência de tipo diferente" (Smith 2008, p.194). Se a experiência momentânea é uma parte da experiência estendida, o caráter da experiência original seria preservado. Contudo, ao defender que a experiência estendida tem uma extensão homogênea, o disjuntivista tem de validar um relato sobre as alucinações momentâneas que não pode admitir, conforme a seguinte situação hipotética. Vamos supor que estimulemos o nervo óptico de modo igual àquele quando a pessoa vê um quadrado amarelo, porém, o estímulo foi tão breve que a pessoa não sabe ao certo o que alucinou. Embora possa dizer que teve 
uma experiência visual, devido à brevidade da experiência a pessoa não consegue dizer especificamente o que pareceu ver. Se não tem certeza que alucinou um quadrado amarelo, talvez ela tenha alucinado um quadrado verde etc. Então, a alucinação momentânea é indiscriminável da percepção momentânea de um quadrado amarelo, e também indiscriminável da percepção momentânea de um quadrado verde, e assim por diante. Assim, para defender que o apelo à extensão homogênea faça sentido para os falsos positivos, deve fazer sentido também para as alucinações momentâneas. Ou seja, deve-se admitir que a pessoa conseguirá especificar o caráter fenomênico da alucinação momentânea ao se estender o tempo da experiência. Contudo:

Uma extensão homogênea pressupõe o fato em questão [sobre qual é o caráter fenomênico da experiência alucinatória momentânea] que diz respeito ao caráter fenomênico da experiência ser estendido, quando esse próprio fato consiste das possibilidades de discriminação justo em relação a tal extensão homogênea. Uma situação ótima pode ser especificada somente pela dependência da noção de igualdade do caráter fenomênico, que em si própria poderia ser explicada somente por referência a essa situação ótima (Smith 2008, pp.194-5).

Como estamos admitindo a extensão homogênea para experiências momentâneas, o caráter fenomênico deve ser realizado na alucinação momentânea, pois deve permanecer realizado na extensão temporal. Ora, mas se o disjuntivismo negativo defende que a fenomenologia alucinatória é determinada somente pela propriedade da indiscriminabilidade, se atribuirmos " $F$ " à fenomenologia da alucinação momentânea, a fenomenologia da extensão homogênea também será " $F$ ", isto é, continuará indeterminada para a pessoa. Então, o disjuntivista tem de recorrer a uma explicação circular para dar um relato da natureza das alucinações momentâneas, pois não pode recorrer a outras características mentais, além da propriedade da indiscriminabilidade.

Resta ao disjuntivista defender que uma situação ótima pode ser alcançada ao considerarmos um ser para quem a brevidade temporal não é um impedimento pessoal. Um ser com uma super acuidade visual poderia diferenciar o falso positivo de uma experiência sensorial, pois a brevidade temporal não seria um problema para ele. Porém, quando apelamos a tal ser, outro tipo de circularidade surge ao tentamos explicar as alucinações momentâneas. Teríamos de referir "nossos casos de experiências não sensoriais a outra pessoa para julgamento" (Smith 2008, p.195).

Se não existe uma situação ótima discriminatória para os falsos positivos, isto é, uma situação possível que revele que o impedimento discriminatório é de ordem pessoal, os falsos positivos são indiscrimináveis impessoalmente de percepções verídicas. Ao não separar alucinações de falsos positivos, o disjuntivismo negativo não oferece um relato adequado para as alucinações.

Os falsos positivos colocam o disjuntivismo negativo num dilema. Se a indiscriminabilidade impessoal é suficiente para uma experiência ser sensorial, temos de 
admitir, erroneamente, que os falsos positivos também são experiências sensoriais. Se afirmar que os falsos positivos são experiências não sensoriais, o disjuntivista tem de abdicar do critério epistêmico negativo se quiser que os falsos positivos não sejam selecionados junto às alucinações. A saída para o dilema é mostrar que existe uma situação possível na qual uma pessoa discriminaria o falso positivo de uma percepção verídica momentânea. No entanto, ao tentar mostrar que existe uma situação ótima para a discriminação, o disjuntivista tem de recorrer a uma explicação circular para dar um relato da natureza alucinatória.

Diferentemente das sugestões pós-hipnóticas e dos sonhos lúcidos, os falsos positivos são um sério problema para o disjuntivista negativo. Talvez se possa discutir o caráter sensorial das alucinações na tentativa de salvar o disjuntivismo negativo, porém, considerando os argumentos a favor e contra o disjuntivismo negativo, o critério epistêmico negativo deve ser rejeitado, pois se tivéssemos outras propriedades para explicar as alucinações, além da propriedade da indiscriminabilidade, alucinações seriam discriminadas de falsos positivos.

A conclusão é que o disjuntivismo negativo não diferencia alucinações de falsos positivos, pois não existe situação ótima na qual a pessoa consiga discriminar estas experiências. Se não é suficiente para selecionar experiências sensoriais entre experiências em geral, o disjuntivismo negativo não explica as alucinações. Consequentemente, precisamos postular outras propriedades mentais para explicar a natureza alucinatória. Isso, porém, ameaça o realismo ingênuo, pois a postulação de uma natureza positiva para as alucinações gera o problema da redundância explicativa, ou seja, gera uma indeterminação na fenomenologia da perceptiva verídica.

\subsection{A não necessidade do critério epistêmico negativo}

Tratemos agora da objeção de Siegel (2008), segundo a qual o disjuntivismo negativo não fornece as condições necessárias para uma experiência ser alucinatória, pois o critério epistêmico negativo não precisaria ser satisfeito por algumas alucinações.

Como vimos, a noção de indiscriminabilidade disjuntivista é fixada no conhecimento obtido via reflexão introspectiva, ou seja, a pessoa julgará sua experiência indiscriminável de uma percepção verídica com base na sua introspecção. Diferentemente dos humanos, existem seres que não fazem esses julgamentos, pois não têm a sofisticação cognitiva necessária para refletir sobre a própria experiência. Para Siegel (2008, p.210), ao caracterizar alucinações pelo critério epistêmico negativo, não conseguimos explicar as alucinações de seres que não refletem introspectivamente. Vejamos como a filósofa chega a essa conclusão, para depois avaliarmos seus argumentos.

Considere que a alucinação humana de uma banana seja introspectivamente indiscriminável da percepção de uma banana e que (conforme o disjuntivismo nega- 
tivo) a natureza alucinatória é circunscrita à propriedade da indiscriminabilidade. Assim, por portar a propriedade de ser indiscriminável da percepção de uma banana, a alucinação da pessoa será de uma banana, pois nada mais é necessário para que se alucine uma banana. Em outras palavras, ao fazer o julgamento sobre o que aparece à sua consciência, o humano tem acesso epistêmico à propriedade da indiscriminabilidade que torna a alucinação uma experiência sensorial de uma banana. No caso dos humanos, a alucinação encontra a propriedade da indiscriminabilidade, porém, essa identificação não ocorreria no caso dos cachorros, que não refletem introspectivamente.

Dado o critério epistêmico negativo e o fato de que um cachorro não forma juízos introspectivos, não podemos afirmar que o cachorro tem uma alucinação de uma banana porque sua experiência teria a propriedade de ser indiscriminável da percepção de uma banana, pois não está acessível à cognição do cachorro a propriedade que torna a sua experiência uma alucinação de uma banana. Então, um cachorro, quando alucina, não está em posição de saber se sua experiência é de uma banana, de um tomate, do seu tutor etc. Conclui-se que todas as alucinações caninas parecerão iguais.

O problema pode ser posto de outra maneira. Como o cachorro diferenciaria a alucinação de $X$ de uma alucinação de $Y$, se a experiência alucinatória canina é determinada somente em termos epistêmicos? Se o cachorro não é capaz de saber que está tendo uma alucinação indiscriminável da percepção de $X$, ou que está tendo uma alucinação indiscriminável da percepção de $Y$, as experiências alucinatórias de $X$ e $Y$ lhe parecerão as mesmas. A insuficiência cognitiva canina não permite ao cão acessar a propriedade que faz com que a alucinação de uma banana seja discriminável da alucinação de um tomate.

Observemos que não se trata de dizer que o cachorro não diferencia percepções verídicas, pois existiriam propriedades constituintes das experiências perceptivas verídicas - as propriedades fenomênicas ingênuas - por meio das quais o cachorro faria a discriminação. Contudo, o disjuntivismo negativo não forneceria recursos explicativos para alucinações caninas. Para ter alucinações diferentes, o cachorro teria de refletir introspectivamente sobre o que aparece a sua consciência, mas isso não é possível para ele. Caso fosse atribuída às alucinações uma natureza positiva, o cachorro não dependeria de algo que não tem para discriminar experiências alucinatórias. Isso, porém, seria abdicar do critério epistêmico negativo.

Em réplica, Martin (2009[2004], 2006) afirma:

Um cachorro poderia não discriminar uma experiência de outra experiência ao não fazer um juízo se elas são diferentes ou idênticas em absoluto, mas isso não é afirmar que nós não podemos julgar, quando atribuímos aos cachorros tais experiências, que existe um evento que poderia ou não ser diferente de outra experiência (Martin 2009[2004], p.305).

Ao considerar a incapacidade discriminatória canina, Siegel (2008) estaria utilizando 
a noção pessoal de indiscriminabilidade, pois a incapacidade discriminatória canina envolve uma incapacidade específica, a incapacidade cognitiva do cão para fazer o julgamento discricionário. Divergentemente, experiências indiscrimináveis para o disjuntivismo negativo são aquelas indiscrimináveis sob o ponto de vista impessoal, ou seja, aquelas na quais inexistem impedimentos de ordem pessoal para fazer a discriminação. Desse modo, não é porque o cachorro não consegue diferenciar suas alucinações, que a natureza alucinatória canina não esteja circunscrita somente à propriedade da indiscriminabilidade.

De forma mais clara, como a indiscriminabilidade impessoal é uma noção definida em termos do julgamento, o cachorro não acessa a propriedade da indiscriminabilidade. Mas isso não implica que o disjuntivismo negativo não forneça as condições necessárias para a experiência alucinatória de seres sem a capacidade para refletir sobre a própria experiência. Não é porque cães não têm o acesso epistêmico que humanos têm à propriedade da indiscriminabilidade, que a alucinação canina não esteja circunscrita somente à propriedade da indiscriminabilidade. Por isso, o disjuntivismo negativo forneceria as condições necessárias também para as alucinações caninas.

$\mathrm{O}$ apelo à indiscriminabilidade impessoal, porém, não resolveria a questão. Ao admitir que o critério epistêmico negativo é necessário para a alucinação canina, Siegel (2008, p.211), defende que o disjuntivismo negativo precisa especificar o que é para a alucinação canina ter a propriedade de ser indiscriminável impessoalmente da correspondente percepção genuína canina.

Para explicar a natureza da alucinação canina, não podemos utilizar a indiscriminabilidade impessoal como a aplicamos às alucinações humanas, pois cachorros não tem reflexão introspectiva. Também não podemos recorrer a algo para explicar a presença da propriedade da indiscriminabilidade nas alucinações caninas, pois isso seria buscar outras propriedades mentais nas alucinações caninas, violando o critério epistêmico negativo. Siegel (2008, p.211) afirma que a propriedade da indiscriminabilidade deve ser entendida por meio de alguma situação contrafactual à noção epistêmica de alucinação, tais como as abaixo:

(1) se idealmente o cachorro pudesse refletir sobre a situação, ele não seria capaz de saber por reflexão que ele não estava percebendo veridicamente uma salsicha. (2) se eu pudesse idealmente refletir sobre a situação do cachorro, eu não seria capaz de saber por reflexão que ele não estava percebendo veridicamente uma salsicha. (3) se um introspectador ideal estivesse na situação do cachorro, tal introspectador não seria capaz de saber por reflexão que ele não estava percebendo veridicamente uma salsicha (Siegel 2008, p.212).

Admitido que as três situações exemplificam o que é a propriedade da indiscriminabilidade alucinatória canina, o cachorro poderia alucinar uma salsicha diferentemente de como alucina seu tutor. Porém, esses três modos de entender como a propriedade 
da indiscriminabilidade caracterizaria a alucinação canina não resolvem a questão. O problema repousaria na tentativa de explicar em primeiro lugar o que seria para o estado mental alucinatório canino ter a propriedade de ser indiscriminável impessoalmente de uma percepção verídica. Se é preciso especificar o que é para uma alucinação ter a propriedade da indiscriminabilidade, então existe alguma explicação mais fundamental a ser dada para a natureza alucinatória. Mas buscar essa explicação contradiz a tese disjuntivista na qual o máximo que podemos falar sobre a natureza das alucinações é que elas são indiscrimináveis das percepções correspondentes. Por conseguinte, resta ao disjuntivista uma explicação circular, tendo em vista que tem de recorrer à propriedade da indiscriminabilidade para explicar a indiscriminabilidade que as situações contrafactuais deveriam explicar. Se mesmo recorrendo à noção impessoal de indiscriminabilidade, não consegue bloquear a objeção na qual o critério epistêmico negativo não é necessário para as alucinações caninas, o disjuntivismo negativo não explica satisfatoriamente as alucinações.

Ambos os lados do debate, Martin (2006) e Siegel (2008), concordam que, endossado o critério epistêmico negativo, cachorros teriam alucinações experiencialmente iguais, pois eles não têm acesso epistêmico à propriedade da indiscriminabilidade. Embora Martin (2006) argumente que, sob o ponto de vista impessoal, a alucinação canina de um tomate é diferente da alucinação canina de uma cenoura, tem o ônus de especificar o que é para a alucinação canina ter a propriedade da indiscriminabilidade, gerando um dilema. Se tentar explicar a propriedade da indiscriminabilidade canina, o disjuntivista negativo viola o critério epistêmico negativo, pois tem de recorrer a uma explicação para as alucinações mais fundamental do que a propriedade da indiscriminabilidade. Se não quiser violar o critério epistêmico negativo, tem de recorrer a uma explicação circular para a propriedade da indiscriminabilidade presente na alucinação canina.

Mas é sensato afirmar que cachorros não têm alucinações diferentes? Experimentos científicos têm levado os pesquisadores a crerem que animais não humanos alucinam. Blom (2010, p.26) relata que o comportamento de animais submetidos a substâncias psicoativas indicam que eles podem alucinar. Fish apud Yamamoto e Ueki (2008, p.154) afirma que experimentos com pequenos roedores parecem indicar que eles alucinam. Contudo, alucinações em animais não humanos não são tomadas como um fato. A dificuldade nesse tipo de pesquisa é o fato de que animais não humanos não podem relatar se estão vendo algum objeto que justificaria certos comportamentos de caça, por exemplo. Nesse sentido, embora possa parecer que o animal tenha tentado pegar algo no ar que não está lá, não é certo que estava alucinando. Ou seja, o comportamento do animal não justificaria a dedução de que ele está tendo uma experiência alucinatória.

A meu ver, dois fatores incidem contra o disjuntivismo negativo: 1) Embora não tenhamos um consenso científico a respeito das alucinações em certos animais, pois 
não estar demonstrado que animais não humanos alucinam, parece-me mais razoável defender que cachorros, não apenas alucinam, mas têm alucinações diferentes. 2) O disjuntivismo negativo declara que alucinações caninas portam a propriedade da indiscriminabilidade, porém, não tem recursos teóricos satisfatórios para explicar como essas alucinações seriam caracterizadas pela propriedade da indiscriminabilidade.

O que me parece mais razoável é afirmar que o disjuntivismo negativo não fornece as condições necessárias para experiências alucinatórias em geral, tendo em vista que alucinações caninas, felinas etc. não precisam satisfazer o critério epistêmico negativo. Se uma explicação adicional para as alucinações de seres que não refletem sobre sua experiência é necessária, devem existir outras propriedades mentais caracterizando a natureza alucinatória.

\section{O disjuntivismo eliminativista}

O disjuntivismo eliminativista de Fish $(2008,2009)$ recorre a uma caracterização epistêmica das alucinações e ao eliminativismo fenomênico para defender o realismo ingênuo do argumento causal. Se para os disjuntivistas fenomênicos a indiscriminabilidade alucinatória provém da incapacidade de a pessoa discriminar sua experiência de uma percepção verídica, para Fish $(2008,2009)$ o que fixa a indiscriminabilidade, isto é, o que torna uma alucinação indiscriminável de uma percepção verídica, são efeitos cognitivos suficientemente semelhantes aos efeitos cognitivos de uma percepção verídica.

Para o disjuntivista fenomênico, como vimos, as crenças sobre experiências perceptivas não são provenientes da observação de algo interno, pois a introspecção não é tomada como um sentido interno que nos daria sempre acesso às propriedades da experiência. Assim, a concepção de introspecção não observacional permite ao disjuntivista fenomênico explicar porque a pessoa que alucina falha em saber que não está tendo uma percepção verídica, ainda que sua alucinação pareça ter a mesma fenomenologia de uma percepção verídica.

Mas como o disjuntivismo eliminativista explica a indiscriminabilidade introspectiva alucinatória se não pode recorrer a um caráter fenomênico comum a alucinações e percepções verídicas?

Segundo Fish $(2008,2009)$, a adoção de um modelo de introspecção não observacional permite endossar um conceito de indiscriminabilidade segundo o qual "dois estados mentais são indiscrimináveis porque eles se registram equivalentemente na introspecção, de modo que isso é entendido como requerendo que os dois estados geram crenças introspectivas equivalentes" (Fish 2008, p.151). Assim, para que o estado mental alucinatório seja registrado na introspecção como se fosse um estado 
mental perceptivo, a alucinação deve produzir crenças que levam a pessoa a julgar que está vendo um objeto físico. A indiscriminabilidade alucinatória estaria, portanto, fundada em crenças sobre a experiência equivalentes às crenças geradas na percepção verídica. Mas "as crenças introspectivas geradas pela alucinação não precisam incluir necessariamente cada e toda crença que a percepção correspondente geraria, mas seria somente necessário que fossem o que poderíamos chamar suficientemente similares" (Fish 2008, p.152). Desse modo, a equivalência introspectiva que uma alucinação teria com a percepção correspondente não implicaria na identidade entre o estado mental alucinatório e o estado mental perceptivo.

Considerando que as crenças introspectivas alucinatórias são os efeitos cognitivos gerados numa alucinação, uma alucinação será introspectivamente indiscriminável de uma percepção quando produzir efeitos cognitivos suficientemente similares àqueles produzidos pela respectiva percepção. Desse modo, o que é relevante para a indiscriminabilidade experiencial alucinatória são os efeitos alucinatórios. A indiscriminabilidade alucinatória seria o resultado somente do conjunto de crenças introspectivas produzidas pela alucinação.

A concepção de alucinação de Fish (2008, p.153) é baseada na teoria de Armstrong (1961, p.83), na qual uma alucinação é constituída por duas falsas crenças, uma de primeira ordem e outra de alta ordem. A crença de primeira ordem é aquela que a pessoa tem sobre o mundo, tal como "creio que existe um livro em cima da mesa". A crença de alta ordem é aquela que a pessoa tem sobre sua experiência, tal como "acredito que eu estou vendo um livro". Crenças de primeira ordem podem ser derivadas de crenças de alta ordem, pois ao crer que está vendo um gato preto diante de si, a pessoa tem de crer que existe um gato preto ali.

Tal como Armstrong (1961), Fish (2009, p.98) afirma que não precisamos recorrer a nada além de crenças para explicar o que ocorre na alucinação, desde o que a pessoa pensa, diz e faz até a falsa crença que sua experiência tem fenomenologia. Porém, se para Armstrong (1961) as crenças de alta ordem são constituintes da experiência alucinatória, para Fish (2008, pp.154-5) as crenças são os efeitos da alucinação, tão somente. Com isso, pode-se defender que crenças de alta ordem não são necessárias para toda e qualquer alucinação e, com isso, escapar da objeção que incide contra a teoria de Armstrong (1961) de que outros animais não alucinam porque não têm crenças de alta ordem.

Diferentemente dos outros animais, que não formam crenças sobre suas experiências, para que a alucinação humana se qualifique como suficientemente similar a uma percepção e, portanto, se qualifique como indiscriminável, crenças de alta ordem são necessárias. As crenças de alta ordem são os efeitos cognitivos alucinatórios necessários para que humanos, ou para que animais não humanos que tenham tal capacidade cognitiva, ${ }^{16}$ creiam que estão vendo um objeto físico.

A produção de efeitos cognitivos suficientemente similares aos produzidos pela 
percepção correspondente e a ausência de fenomenologia seriam, portanto, as condições necessárias e suficientes para que um estado mental se qualifique como uma alucinação. A diferença entre experiências alucinatórias e experiências não sensoriais residiria somente no fato de que o estado mental alucinatório é indiscriminável do estado mental perceptivo. ${ }^{17}$

Mas como explicar o fato de que na experiência alucinatória existe "algo que é como alucinar" para o sujeito da experiência, pois, se considerarmos a ausência da fenomenologia nas alucinações, o disjuntivismo eliminativista parece negar que existe "algo que é como alucinar" para o sujeito da alucinação? A resposta é que, mesmo se:

... uma alucinação não tiver caráter fenomênico, pelo motivo que ela produz os mesmos efeitos cognitivos de uma percepção verídica, um ser convenientemente sofisticado ainda acreditaria que sua experiência tem caráter fenomênico, pensaria que existe algo que é como estar alucinando, e afirmaria que está tendo uma experiência de certo tipo, embora estivesse errado (Fish 2009, p.98).

Na percepção verídica, é "em virtude de a experiência ter caráter fenomênico que existe algo que é como estar nesse estado mental" (Fish 2008, p.145). Ou seja, é o caráter fenomênico que explica a perspectiva subjetiva, ou ponto de vista em primeira pessoa, na percepção verídica. Já na alucinação, o caráter fenomênico aparente seria a consequência da falsa crença de que se está vendo um objeto físico, tendo em vista que "é somente porque antecedentemente existe algo que é como ver $X$ que a mera crença de que alguém está vendo $X$ é suficiente para colocar a pessoa na posição de fazer essa afirmação honestamente (...) Existe, de fato, algo que é como [alucinar]" (Fish 2008, pp.160-1). A falsa crença de crer estar vendo um objeto físico explica por que "existe algo que é como estar alucinando".

Desse modo, o fato de que existe "algo que é como estar alucinando $X$ " é explicado de modo derivativo, ou seja, baseado na percepção verídica que já ocorrera de $X$. Então, não se trata de o disjuntivista eliminativista afirmar que não existe "nada que é como alucinar", mas apenas de dissociar a expressão "existe algo que é como alucinar" da fenomenologia que alucinações teriam. A afirmação de que "existe algo que é como estar num estado mental" se torna verdadeira se o estado mental tem fenomenologia, como nas percepções verídicas, ou se o estado mental for indiscriminável de uma percepção verídica, como nas alucinações. Portanto, é a indiscriminabilidade que explica o fato de que na alucinação "existe algo que é como alucinar".

Se alucinações não têm fenomenologia e se a natureza alucinatória é circunscrita às crenças perceptivas verídicas, o fato de existir para a pessoa "algo que é como estar alucinando" é uma questão somente da falsa crença de estar tendo uma percepção verídica, permitindo acomodar o fato de que existe "algo que é como estar aluci- 
nando" para quem alucina. Isso implica que a pessoa que alucina não é um zumbi filosófico, para quem não existe "algo que é como estar alucinando".

\subsection{A insuficiência explicativa}

Se o efeito cognitivo relevante para que o evento mental seja uma alucinação indiscriminável para uma pessoa é ter crenças de alta ordem suficientemente similares àquelas produzidas na percepção verídica, segundo Fish (2009), para seres que não têm a sofisticação cognitiva para refletir sobre sua experiência, o fator determinante para que tenham uma alucinação indiscriminável é o seu comportamento. Por exemplo, consideremos que um gato, sempre que vê uma borboleta voando, estica a pata em direção à borboleta de certa maneira. Curiosamente, um dia vemos que o gato, nas mesmas condições ambientais, tem o mesmo comportamento, mas não vemos nada voando. Ora, o gato parece estar alucinando uma borboleta.

Segundo o disjuntivismo eliminativista, para que tenha uma alucinação indiscriminável, o estado mental do gato deve ter efeitos cognitivos que o tornem indiscriminável do estado mental na percepção verídica. Como a alucinação felina é uma questão de efeitos comportamentais dependentes do comportamento felino numa situação já vivenciada, a alucinação do felino é uma questão de comportamentos observados.

Entretanto, para Siegel (2008, p.216), existem alucinações animais inexplicáveis para o disjuntivismo eliminativista. A caracterização da natureza alucinatória somente pelo comportamento animal seria insatisfatória para explicar certas alucinações, como a alucinação de uma borboleta por um gato que, por estar letárgico, não exibe qualquer comportamento. Como explicar o estado mental do gato nessa situação?

Para explicar a experiência alucinatória do gato letárgico, o disjuntivista eliminativista não pode recorrer a evidências comportamentais, pois estas estão ausentes. Crenças de alta ordem também não é um recurso explicativo disponível, pois gatos não introspectam experiências. ${ }^{18}$ Ora, se existe uma alucinação indiscriminável sem efeitos cognitivos e se não existem outros recursos para explicar a alucinação felina, certas alucinações escapam à explicação disjuntivista. Então, deve existir alguma propriedade nas alucinações que explica o estado mental do gato letárgico.

Em réplica, Fish (2009) afirma que Siegel (2008) distorce sua teoria:

Ela [Siegel], então, toma essa possibilidade para indicar que um gato poderia alucinar uma borboleta, mesmo se ele não atacasse objetos imaginários no ar. Mas, então, se um gato repousa calmamente num canto, qual evidência nós teríamos para afirmar que o gato, todavia, estava alucinando uma borboleta? Insistir que é possível para um gato alucinar na ausência de evidência comportamental é dar como certo que nós podemos identificar um 
estado mental como uma alucinação por referência a certas características intrínsecas que ela tem (Fish 2009, pp.104-5, nota 26).

Estaria suposto na objeção de Siegel (2008) que alucinações têm características outras além dos efeitos cognitivos, pois a filósofa dá como certo que o gato letárgico alucina. Afirmar que o gato doente alucina na ausência de respostas comportamentais é pressupor que a alucinação felina não pode ser circunscrita somente ao comportamento. Desse modo, sua objeção não atingiria o disjuntivismo eliminativista.

Considerando os argumentos a favor e contra o disjuntivismo eliminativista, Siegel (2008) desconsidera que um gato doente não pode alucinar na ausência dos efeitos cognitivos relevantes, quais sejam, comportamentos similares aos comportamentos apresentados na percepção verídica. Então, ela comete uma petição de princípio quando utiliza o que deve ser provado - outras propriedades além dos efeitos cognitivos - para objetar o disjuntivismo eliminativista. Embora pareça ser pouco razoável a tese de que o gato letárgico não alucina por não apresentar certos comportamentos, não se pode negar a possibilidade teórica da ausência alucinatória nessa situação.

Outra filósofa que contesta a teoria de Fish (2008, 2009) é Logue (2010). Ao recorrer somente às crenças de alta ordem para explicar alucinações humanas, o disjuntivismo eliminativista não responderia a questões cruciais:

O que em primeiro lugar faz da minha experiência o tipo de coisa que naturalmente gera a crença de que existe uma banana amarela na minha frente? Como a minha experiência deve ser e qual a estrutura fundamental que ela deve ter para minha experiência ter esse papel [explicativo]? Em outras palavras, parece existir uma profunda conexão entre a minha experiência perceptiva e a crença de que existe uma banana amarela diante de mim. No que consiste essa conexão? (Logue 2010, p.33).

Uma teoria da percepção deve explicar porque a experiência visual de uma banana tem os efeitos cognitivos que apresenta e a conexão entre essa experiência e a crença perceptiva. Nas percepções verídicas, a crença de que estou vendo uma banana provém da experiência visual da banana, e essa experiência é uma questão de eu ter contato direto com uma banana. Isso explica no que consiste a conexão entre a visão de uma banana e a crença de que estou vendo uma banana. Contudo, para as alucinações, o disjuntivismo eliminativista não pode recorrer à explicação análoga a da percepção verídica.

Se a alucinação humana de uma banana é uma questão somente de efeitos cognitivos relevantes (crenças de alta ordem), "a natureza fundamental da alucinação não explica porque ela [a alucinação] gera essa crença. Antes, o fato de que essa alucinação gera essa crença é apenas uma questão de definição" (Logue 2010, p.33). 
Assim, não são explicadas a conexão entre a experiência alucinatória de uma banana e a (falsa) crença de que se está diante de uma banana, e o que gera a crença alucinatória.

Considerando que caracteriza a natureza alucinatória somente por efeitos cognitivos, se quiser explicar porque uma experiência tem os efeitos cognitivos que apresenta, o disjuntivista eliminativista tem de oferecer uma explicação circular: quando eu alucino, tenho a (falsa) crença de que estou vendo uma banana porque tenho uma alucinação indiscriminável de uma banana, cuja indiscriminabilidade é explicada pela (falsa) crença que estou vendo uma banana.

Antevendo tal crítica, Fish (2009) contesta que sua teoria é incompleta por não explicar porque a experiência alucinatória tem os efeitos cognitivos que têm.

Pelo motivo de um evento mental qualificar-se como alucinação somente quando tem os mesmos tipos de efeitos que certos tipos de percepções verídicas têm, perguntar porque alucinações têm esses tipos de efeitos seria semelhante a perguntar o que solteiros têm em comum em virtude de nenhum deles estar casado (Fish 2009, p.114, grifos do autor).

Ao caracterizar as alucinações somente por efeitos cognitivos, não teria sentido perguntar porque uma alucinação tem crenças de alta ordem, na medida em que a essência alucinatória seria ter efeitos cognitivos suficientemente similares aos de uma percepção genuína e "não em alguma propriedade identificável antecessora ao evento" (Fish 2009, p.114). Assim, a própria definição de alucinação explicaria por que uma crença é produzida pela experiência alucinatória. Se alucinações são estados mentais que têm efeitos que levam a pessoa a crer que está vendo um objeto físico, as crenças perceptivas alucinatórias são explicadas pela própria definição de alucinação.

Certamente a crítica de Logue (2010) não é decisiva contra o disjuntivismo eliminativista, mas mostra uma deficiência explicativa dessa teoria. Ao circunscrever a experiência alucinatória às crenças de alta ordem, Fish (2009) trata o explanans analiticamente equivalente ao explanandum. Com isso, não existe espaço teórico para se oferecer uma explicação adequada para as crenças geradas na experiência alucinatória. Talvez o disjuntivista eliminativista possa explicar as crenças alucinatórias recorrendo ao fato de que "existe algo que é como alucinar" para quem alucina, porém, seria um equívoco. Na percepção verídica, ele pode defender que crenças perceptivas provém do fato de que "existe algo que é como" ter uma percepção verídica. É porque percepções verídicas têm fenomenologia que "existe algo que é como" ver um objeto físico. No entanto, Fish $(2008,2009)$ tem de inverter a ordem de explicação utilizada na percepção verídica para explicar a geração de crenças alucinatórias, ou seja, é porque alucinações são crenças de alta ordem que "existe algo que é como" alucinar.

Logue (2010) apresenta uma segunda crítica, a de que o disjuntivismo eliminativista não tem recursos para explicar alucinações diferentes. Embora Fish (2008, 
2009) explique as alucinações de animais, como cães e gatos, recorrendo aos efeitos comportamentais, mesmo nos casos de animais que alucinam exibindo comportamentos exibidos na percepção verídica existiriam situações alucinatórias indistinguíveis para o disjuntivismo eliminativista. Nesse sentido, comparemos duas experiências: a alucinação que um cachorro tem de um gato preto contra uma parede verde e a alucinação que esse cachorro tem de um gato branco contra uma parede verde, nas mesmas condições ambientais. A experiência alucinatória na situação 1 é diferente da experiência alucinatória na situação 2 , porém, o disjuntivismo eliminavista não tem recursos para diferenciá-las. É improvável que a cor do gato influencie o comportamento do cachorro (supondo que o cachorro não tenha ojeriza a essa ou aquela cor de gato). Teríamos de afirmar que as alucinações são indiscrimináveis da percepção verídica de um gato preto e da percepção verídica de um gato branco.

Ao contrário da primeira objeção de Logue $(2010)$, Fish $(2008,2009)$ não prevê sua segunda objeção. Ambas situações alucinatórias, a alucinação do gato branco e a alucinação do gato preto, poderiam ser distinguidas se recorrêssemos ao caráter fenomênico alucinatório, mas esse recurso não está disponível ao eliminativista fenomênico. Então, essa é uma deficiência explicativa do disjuntivismo eliminativista, pois é incapaz de explicar alucinações claramente diferentes, tais como a alucinação canina de um gato preto e a alucinação canina de um gato branco. Desse modo, é razoável afirmar que somente "comportamentos" não são suficientes para explicar a natureza alucinatória de animais que não têm crenças de alta ordem.

Se a objeção de Siegel (2008) ao disjuntivismo eliminativista comete uma petição de princípio, as objeções de Logue (2010), embora não decisivas, enfraquecem o disjuntivismo de Fish $(2008,2009)$ ao evidenciarem suas deficiências explicativas enquanto teoria da percepção.

\subsection{O vermelho supersaturado}

Embora negue que alucinações tenham fenomenologia, Fish (2008, pp.160-1) afirma que na experiência alucinatória existe um ponto de vista em primeira pessoa, ou seja, "existe algo que é como alucinar", de modo que a condição para existir a perspectiva subjetiva alucinatória é a de que tenha existido "algo que é como" ter a correspondente percepção verídica. Desse modo, a perspectiva subjetiva numa alucinação deriva da perspectiva subjetiva da correspondente percepção genuína. "A similaridade em termos de como é perceber $X$ e alucinar $X$ deriva da indiscriminabilidade desses estados mentais" (Fish 2008, p.161). Consequentemente, o disjuntivismo eliminativista tem de explicar "como é alucinar $X$ " sempre em referência a percepção verídica de $X$.

Entretanto, existem alucinações que contestam a dependência explicativa que uma alucinação teria em relação a uma percepção verídica e, portanto, a perspectiva 
de primeira pessoa alucinatória não dependeria da perspectiva de primeira pessoa na percepção verídica. Tais alucinações nos permitem negar que "como é alucinar" deriva de "como é perceber" e a experiência do vermelho supersaturado é um desses casos.

O vermelho supersaturado é uma pós-imagem, ou seja, uma experiência visual "que ocorre em resposta ao estímulo inicial de luz nos olhos, que é tipicamente relatada depois que o estímulo visual foi modificado ou removido" (Blom 2015, p.33). A experiência alucinatória do vermelho supersaturado foi relatado por Hurvich (1981, p.187) após um experimento sobre a percepção de cores. Inicialmente, a pessoa é colocada numa sala escura e exposta a uma luz verde monocromática. Então, a luz verde é desligada e a sala iluminada. Ao olhar para uma superfície acromática, a pessoa verá uma pós-imagem de cor vermelha. Então, ao olhar para uma pequena parte da parede pintada de vermelho, a pessoa terá a experiência do vermelho supersaturado.

Uma pessoa não pode ter a percepção verídica do vermelho supersaturado, pois o vermelho supersaturado pode ser experienciado somente na alucinação. Quando a pessoa passa por esta experiência, "existe algo que é como alucinar" o vermelho supersaturado. Portanto, contrariamente ao disjuntivismo eliminativista, não se pode derivar a perspectiva subjetiva do vermelho supersaturado de uma percepção verídica, uma vez que "não existe algo que é como" ter a percepção verídica do vermelho supersaturado. Analisemos com mais vagar o exposto.

Segundo Fish $(2008,2009)$, a indiscriminabilidade é o que explica o fato de que na alucinação "existe algo que é como" alucinar, pois "a afirmação de que existe algo que é como estar num estado mental é verdadeira porque ela possui caráter fenomênico ou porque ela é indiscriminável de um estado [mental] que tem caráter fenomênico" (Fish 2008, p.161). Então, não deveria existir uma perspectiva subjetiva na experiência do vermelho supersaturado, pois ela não atende a nenhum dos dois critérios acima. Contrariamente ao previsto pela teoria, "existe algo que é como" experienciar o vermelho supersaturado.

O disjuntivista eliminativista também não pode afirmar que a perspectiva subjetiva do vermelho supersaturado é uma questão de a pessoa ter uma falsa crença, na medida em que não existiu anteriormente a percepção correspondente. Desse modo, não tem sentido afirmar que é por causa de alucinações serem crenças que "existe algo que é como" alucinar. Ao contrário, é a perspectiva subjetiva na alucinação do vermelho supersaturado que produz a respectiva crença. Então, como explicar a perspectiva de primeira pessoa na experiência alucinatória em questão?

Considerando que o vermelho supersaturado pode ser somente alucinado, é mais razoável negar o eliminativismo fenomênico e defender a existência de um caráter fenomênico alucinatório do que explicar a perspectiva subjetiva da pessoa na alucinação do vermelho supersaturado. Isso nos leva a concluir, contrariamente a Fish 
(2008, 2009), que alucinações têm fenomenologia. Se é um equívoco caracterizar epistemicamente a natureza alucinatória somente por efeitos cognitivos, o disjuntivismo eliminativista não se sustenta.

\section{Conclusão}

Martin (2004[2009], 2006) e Fish $(2008$, 2009) utilizam o disjuntivismo fenomênico em defesa do realismo ingênuo contra o argumento causal. Embora ambas as estratégias de resposta se baseiem na caracterização epistêmica da alucinação, suas teorias se diferenciam justamente pelo relato que oferecem à natureza alucinatória. O disjuntivismo negativo adota o critério epistêmico negativo para caracterizar alucinações, explicando a fenomenologia alucinatória pela propriedade da indiscriminabilidade. No entanto, reduzir a natureza alucinatória à propriedade da indiscriminabilidade é insuficiente para discriminar alucinações de experiências não sensoriais. Outro problema com o disjuntivismo negativo é que o critério epistêmico negativo também não é necessário para a ocorrência de certas alucinações. Dado a não suficiência e a não necessidade do critério epistêmico negativo, o disjuntivismo negativo não é uma estratégia adequada para defender o realismo ingênuo contra o argumento causal.

O disjuntivismo eliminativista também não é uma boa estratégia de defesa do realismo ingênuo contra o argumento causal, na medida em que não consegue discriminar certas alucinações e não explica adequadamente as crenças geradas na experiência alucinatória, problemas que enfraquecem essa teoria. Mais contundente é a objeção que se baseia na experiência alucinatória do vermelho supersaturado, cuja explicação requer que alucinações tenham caráter fenomênico, contestando o cerne do disjuntivismo eliminativista. Esses argumentos são suficientemente fortes para que o disjuntivista fenomênico que queira defender o realismo ingênuo não adote a estratégia eliminativista em relação à fenomenologia alucinatória.

Mediante o exposto, o disjuntivismo negativo e o disjuntivismo eliminativista são insuficientes para explicar a natureza alucinatória. Se considerarmos as respectivas caracterizações epistêmicas propostas por ambas teorias à natureza alucinatória, precisamos de outras propriedades mentais para explicar as alucinações. Com isso, o problema da redundância explicativa volta a ameaçar o realismo ingênuo, pois propriedades da alucinação concorreriam com objetos físicos na determinação fenomênica da percepção verídica. Por tudo isso, o disjuntivismo fenomênico não consegue defender o realismo ingênuo do argumento causal.

\section{References}

Armstrong, D. M. 1961. Perception and the Physical World. London: Routledge. 
Austin, J. L. 2004[1962]. Sentido e Percepção. Trad. Armando Manuel Mora de Oliveira. São Paulo: Martins Fontes.

Blom, J. D. 2010. Animals and Hallucinations. In: Dictionary of hallucinations, p.26. London: Springer.

Blom, J. D. 2015. Defining and measuring hallucinations and their consequences - what is really the difference between a veridical perception and a hallucination? In: D. Collerton; P.U. Mosimann; E. Perry (eds.) Neuroscience of Visual Hallucinations, pp.23-45. West Sussex: Wiley Blackwell.

Dennett, D. C. 1991. Consciousness Explained. New York: Penguim.

Ffytche, D. 2009. Hallucination. In: T. Bayne; A. Creeremans; P. Wilken (eds.) The Oxford Companion to Consciousness, pp.335-7. Oxford: Oxford University Press.

Ffytche, D. 2013. The Hallucinating Brain. In: F. Macpherson; D. Platchias (eds.) Hallucination: Philosophy and Psychology, pp.45-63. Cambridge, MA: The MIT Press.

Fish, W. 2008. Disjunctivism, Indistinguishability and the nature of Hallucination. In: A. Haddock; F. Macpherson (eds.) Disjunctivism: perception, action, knowledge, pp.144-67. Oxford: Oxford University Press.

Fish, W. 2009. Perception, Hallucination and Illusion. Oxford: Oxford University Press.

Green, C. 1968. Lucid Dreams. Oxford: Institute of Psychophysical Research.

Hellie, B. 2009. Acquaintance. In: T. Bayne; A. Creeremans; P. Wilken (eds.) The Oxford Companion to Consciousness, pp.5-7. Oxford: Oxford University Press.

Hinton, J.M. 1967. Visual Experiences. Mind 76: 212-27.

Hurvich, L. M. 1981. Color vision. Cambridge: Sinauer Associates Inc.

Jamieson, G. A. 2009. Hypnosis. In: T. Bayne; A. Cleeremans; P. Wilken (eds.) The Oxford Companion to Consciousness, pp.352-6.Oxford: Oxford University Press.

Kim, J. 1993. Supervenience and Mind. Cambridge: Cambridge University Press.

Logue, H. 2010. Getting Acquainted with Naïve Realism: Critical Notice of Perception, Hallucination and Illusion. Philosophical Books 51(1): 22-38.

Martin, M. G. F. 2009[2004]. The limits of self-awareness. In: A. Byrne; H. Logue (eds.) Disjunctivism, pp.271-317. Cambridge, MA: The MIT Press.

Martin, M. G. F. 2006. On Being Alienated. In: T.S. Gendler; J. Hawthorne (eds.) Perceptual Experience, pp.354-410. Oxford: Oxford University Press.

Naish, P. 2013. Hallucinations in Hypnosis. In: F. Macpherson; D. Platchias (eds.) Hallucination: Philosophy and Psychology, pp.121-46. Cambridge, MA: The MIT Press.

Robinson, H. 1994. Perception. London: Routledge.

Siegel, S. 2008. The epistemic conception of hallucination. In: A. Haddock; F. Macpherson (eds.) Disjunctivism: perception, action, knowledge, pp.205-26. Oxford: Oxford University Press.

Smith, A. D. 2002. The problem of perception. Cambridge, MA: Harvard University Press.

Smith, A. D. 2008. Disjunctivism and Discriminability. In: A. Haddock; F. Macpherson (eds.) Disjunctivism: perception, action, knowledge, pp.181-204. Oxford: Oxford University Press.

Sturgeon, S. 2008. Disjunctivism about perceptual experience. In: A. Haddock; F. Macpherson (eds.) Disjunctivism: perception, action, knowledge, pp.112-43. Oxford: Oxford University Press.

Waal, F. de 2007. Eu, primata. Trad. Laura Teixeira Mota. São Paulo: Cia. das Letras. 


\section{Notas}

${ }^{1}$ Talvez não seja necessário que toda percepção envolva consciência, se considerarmos os casos de visão cega (blindsight), patologia na qual a pessoa adquire informação sobre alguma parte do cenário sem ter uma experiência consciente dessa parte. Seria um processamento de informação visual com ausência de fenomenologia. No entanto, porque esses casos devem ser entendidos como ampliações da percepção sensível comum, não como casos paradigmáticos, e porque não envolvem o tipo de percepção sensível que interessa ao presente trabalho, nós os deixaremos de lado. Na percepção sensível comum e paradigmática, há consciência do que se percebe.

${ }^{2}$ Essa é a expressão que utilizarei para me referir à experiência ocorrente na percepção verídica.

${ }^{3} \mathrm{~A}$ teoria dos dados dos sentidos também é uma teoria filosófica da percepção segundo a qual a experiência perceptiva é relacional, mas por ser uma teoria pouco defendida atualmente, costuma-se associar "visão relacional" ou "relacionalismo" à concepção da percepção verídica denominada realismo ingênuo.

${ }^{4} \mathrm{O}$ máximo fator comum entre percepções e alucinações é endossado pelos teóricos dos dados dos sentidos e por alguns intencionalistas, para citar duas das teorias concorrentes do disjuntivismo.

${ }^{5}$ Note-se que os disjuntivistas fenomênicos admitem que alucinações podem ser indiscrimináveis das correspondentes percepções sob uma perspectiva de primeira pessoa, ou perspectiva subjetiva. Contudo, existem casos de alucinações indiscrimináveis de percepções nos quais as pessoas sabem que estão alucinando, tal como ocorre por quem tem a síndrome de Charles Bonnet. Segundo Ffytche (2013, p.50), geralmente a síndrome começa dias ou semanas antes de a visão começar a diminuir e, devido à complexidade e detalhes realísticos de algumas das alucinações vivenciadas nessa síndrome, a pessoa pode pensar que está tendo uma percepção. Contudo, invariavelmente, os pacientes aprendem a distinguir suas experiências alucinatórias de uma percepção verídica. Então, talvez devêssemos questionar em primeiro lugar a admissibilidade disjuntivista (e conjuntivista) das alucinações introspectivamente indiscrimináveis. Como nas objeções ao disjuntivismo fenomênico expostas neste artigo também está implícita a admissão de alucinações indiscrimináveis e, portanto, o debate entre disjuntivistas e objetores e objetoras ocorre com o endosso prévio de alucinações introspectivamente indiscrimináveis, não nos aprofundaremos nessa questão.

${ }^{6}$ Poderei me referir aos disjuntivistas fenomênicos somente por "disjuntivistas".

${ }^{7}$ Teóricos dos dados dos sentidos e alguns intencionalistas são conjuntivistas.

${ }^{8}$ Não se deve confundir "acquaintance" russeliana com "acquaintance" disjuntivista. Embora ambas concepções dizem respeito à relação de um sujeito com um objeto, o escopo dos objetos que entram na relação perceptiva muda.

${ }^{9}$ Frequentemente, por similaridade fonética, é usual traduzir supervenience por "superveniência". Nesse caso, por razões de paralelismo, teríamos de usar o verbo "supervir": "a propriedade $A$ supervém à propriedade $B$ ". Mas, a meu ver, esse verbo não é a melhor tradução, pois "sobrevir" captura melhor o sentido que se quer dar à tradução para o português. Além do verbo "sobrevir" ser bastante comum, ele traduz perfeitamente o verbo to supervene. Por que não usar, então, "sobreveniência"?

${ }^{10}$ A sobreveniência é uma relação de covariação e dependência de fenômenos de alto nível 
e fenômenos de baixo nível, no sentido de que, fixadas as propriedades de baixo nível $A$, as propriedades de nível alto $B$ são fixadas. (cf. Kim 1993, p.140).

11 "Se alguma coisa aparece ao sujeito sensorialmente que parece ter uma qualidade particular sensível, então existe algo do qual o sujeito está consciente que possui essa qualidade" (Robinson 1994, p.32).

${ }^{12}$ Talvez se possa discutir o caráter sensorial das alucinações. Contudo, proponentes e objetores do disjuntivismo fenomênico que serão considerados nesse artigo consideram que alucinações são experiências sensoriais.

13 "Começar a fazer alguma coisa muito breve, especialmente sem pensar sobre ela cuidadosamente" (Cf. Longman Advanced American Dictionary 2005, p.876).

14"Muitas das mudanças na experiência reportadas na hipnose parecem indicar rupturas no controle executivo do comportamento e nos processos cognitivos. Isso tem levado ainda outros pesquisadores a propor que a hipnose é o resultado do colapso da organização hierárquica dos processos de controle cognitivo do cérebro. Descobertas eletroencefalográficas e de fMRI convergem em mostrar que o colapso do fluxo de informação (conectividade funcional) entre regiões corticais anteriores que implementam o monitoramento e as funções de controle tanto quanto entre as regiões central ou posterior e anteriores" (Jamieson 2009, p.355).

${ }^{15}$ Naish (2013, p.121), por exemplo.

${ }^{16}$ Se considerarmos as pesquisas de primatólogos, como Waal (2007), outros primatas também parecem ter essa capacidade cognitiva.

${ }^{17} \mathrm{O}$ disjuntivismo eliminativista não endossa um irrealismo fenomênico tal como Dennett (1991), tendo em vista que percepções verídicas teriam propriedades fenomênicas ingênuas que determinariam e constituiriam a experiência perceptiva verídica.

${ }^{18}$ Observemos que o disjuntivismo eliminativista tem recursos explicativos para a percepção verídica visual de uma borboleta por um gato letárgico. Como percepções verídicas são estados mentais com caráter fenomênico, a borboleta e suas propriedades constituem parcialmente a experiência visual e determinam a fenomenologia da experiência perceptiva felina.

\section{Agradecimentos}

Meus agradecimentos aos três pareceristas anônimos pelos comentários e sugestões. 